\title{
PENGARUH EARNING PER SHARE, PRICE TO BOOK VALUE, RETURN ON ASSET, DAN RETURN ON EQUITY TERHADAP HARGA SAHAM SEKTOR KEUANGAN
}

\author{
Yustina Wahyu Cahyaningrum \& Tiara Widya Antikasari \\ Universitas Sebelas Maret, Indonesia \\ Email: yustina.wahyu91@gmail.com
}

\begin{abstract}
Abstrak: Pengaruh Earning Per Share, Price to Book Value, Return on Asset, dan Return on Equity Terhadap Harga Saham Sektor Keuangan. Penelitian ini mempunyai tujuan untuk mengetahui pengaruh Earning Per Share (EPS), Price to Book Value (PBV), Return on Asset (ROA), Return on Equity (ROE) secara simultan maupun parsial terhadap harga saham pada perusahaan sektor keuangan yang terdaftar di Bursa Efek Indonesia tahun 2010-2014. Penelitian ini menggunakan data sekunder berupa laporan keuangan tahunan yang diperoleh dari ICMD dan sumber pendukung yang lain. Teknik pengambilan sampel diambil dengan metode purposive sampling sebanyak 237 perusahaan sektor keuangan dari 255 perusahaan yang terdaftar di ICMD. Data dianalisis dengan analisis regresi linier berganda. Hasil penelitian menunjukkan bahwa variabel EPS, PBV, ROA, dan ROE tahun 2010-2014 secara simultan dan parsial mempunyai pengaruh positif terhadap variabel harga saham.

Kata Kunci: Earning Per Share, Price to Book Value, Return on Asset, Return on Equity, Harga Saham

Abstract: The Influence of Earning Per Share, Price to Book Value, Return on Asset, and Return on Equity to Stock Price in Finance Company. The research purpose is to examine the influence of EPS, PBV, ROA and ROE to stock price simultaneously or partially in finance sector companies listed on Indonesia Stock Exchange (BEI) in 20102014. The research using secondary data based on the annual report taken from Indonesia Capital Market Directory and Indonesia Stock Exchange and other support sources. This study uses purposive sampling and 237 of 255 finance sector companies listed in ICMD used as the sample. This research uses multiple regression analysis. The research result shows that EPS, PBV, ROA, and ROE in 2010-2014 simultaneous and partially positive significantly affected by the stock price.
\end{abstract}

Keyword: Earning Per Share, Price to Book Value, Return on Asset, Return on Equity, Stock Price.

\section{PENDAHULUAN}

Sektor keuangan memegang peranan penting dalam pertumbuhan ekonomi suatu negara. Sektor jasa keuangan yang terdiri dari perbankan, asuransi, pembiayaan kredit, pasar modal, dan lembaga keuangan lainnya mempunyai peranan yang penting dan strategis bagi perekonomian Indonesia. Sektor keuangan bertumbuh $9,1 \%$ pada kuartal I 2016 dengan kontribusi ke Produk Domestik Bruto (PDB) sebesar 4,25\% (m.cnnindonesia.com/ekonomi). Didukung sentimen positif terhadap ekonomi global, perbaikan ekonomi dalam negeri, dan kinerja sektor keuangan yang terus meningkat, para investor akan terus memburu saham perusahaan pada sektor keuangan.

Investor akan melihat laporan kinerja keuangan perusahaan sebelum melakukan keputusan menanamkan modalnya atau tidak. Angka dalam laporan keuangan dapat mempengaruhi kepercayaan investor di 
pasar keuangan. Investor mencari peluang untuk berinvestasi sumber daya tambahan di pasar modal yang paling efisien dan salah satu faktor utama yang setiap investor pilih dalam membuat keputusannya adalah untuk memberikan perhatian khusus pada "harga saham" (Arkan, 2016). Yang menjadi permasalahan adalah ketidakpastian harga saham. Analisis terhadap harga saham merupakan langkah mendasar yang harus dilakukan oleh investor sebelum melakukan investasi, supaya investor tidak terjebak pada kondisi yang merugikan (Apriliyanti,2015).

Teori yang mendasari penelitian ini adalah Teori sinyal yang menjelaskan tentang bagaimana para investor memiliki informasi yang sama mengenai prospek perusahaan sebagai manajer perusahaan. Namun dalam kenyataannya manajer sering memiliki informasi lebih baik dari investor. Asimetri informasi merupakan suatu kondisi di mana informasi privat yang hanya dimiliki investorinvestor yang hanya mendapat informasi saja. Hal tersebut akan terlihat jika manajemen tidak secara penuh menyampaikan semua informasi yang diperoleh tentang semua hal yang dapat mempengaruhi perusahaan, maka umumnya pasar akan merespon informasi tersebut sebagai suatu sinyal terhadap suatu kejadian yang akan mempengaruhi nilai perusahaan yang tercermin melalui harga saham (Sulistyanto, 2008)

Reaksi pasar ditunjukkan dengan adanya perubahan volume perdagangan saham (Jogiyanto, 2010). Pada waktu informasi diumumkan dan semua pelaku pasar sudah menerima informasi tersebut, pelaku pasar terlebih dahulu menginterpretasikan dan menganalisis informasi tersebut sebagai sinyal baik (good news) atau sinyal buruk (bad news). Jika pengumuman informasi tersebut sebagai sinyal baik bagi investor, maka terjadi perubahan dalam volume perdagangan saham. Pengumuman informasi akuntansi memberikan sinyal bahwa perusahaan mempunyai prospek yang baik di masa mendatang (good news) sehingga investor tertarik untuk melakukan perdagangan saham, dengan demikian pasar akan bereaksi yang tercermin melalui perubahan dalam volume perdagangan saham. Dengan demikian hubungan antara publikasi informasi baik laporan keuangan, kondisi keuangan ataupun sosial politik terhadap fluktuasi volume perdagangan saham dapat dilihat dalam efisiensi pasar. Pasar modal efisien didefinisikan sebagai pasar yang harga sekuritasnya telah mencerminkan semua informasi yang relevan.

Keterkaitan antara teori sinyal dengan EPS yaitu Laba atau earning menjadi perhatian investor karena laba yang dihasilkan perusahaan dapat menggambarkan keberhasilan perusahaan, maka semakin besar laba, semakin besar pula kemampuan perusahaan untuk membagikan keuntungan bagi pemegang sahamnya. Hal ini dapat meningkatkan permintaan akan saham, sehingga harga saham pun akan naik, di mana hasil ini sesuai dengan signaling theory yang memberikan sinyal baik pada investor. Nilai PBV akan tinggi apabila kinerja perusahaan baik. Hal ini berarti semakin baik kinerja perusahaan, maka rasio PBV akan semakin meningkat dari tahun ke tahun. Tingginya permintaan akan menyebabkan harga saham meningkat. Hal ini sesuai 
dengan signaling theory karena dapat memberikan informasi positif yang menarik minat investor. Hubungan teori sinyal dengan ROA yaitu apabila nilai ROA meningkat, maka ini berarti perusahaan mampu menggunakan aktivanya secara produktif sehingga dapat menghasilkan keuntungan yang besar. Hal ini dapat dijadikan signal untuk para investor dalam memprediksi seberapa besar perubahan nilai atas saham yang dimiliki. ROE memiliki hubungan dengan teori sinyal apabila ROE meningkat, maka dapat diasumsikan perusahaan mampu menunjukkan efisiensi dalam penggunaan modal sendiri. Hal ini dapat dijadikan signal yang baik bagi para investor untuk membeli saham.

\section{Darmadji \& Fakhrudin}

(2012:149) menyatakan bahwa dalam analisis sekuritas ada dua pendekatan yang digunakan yaitu analisis fundamental dan teknikal. Faktor fundamental merupakan salah satu cara untuk melakukan penilaian saham dengan mempelajari atau mengamati berbagai indikator yang terkait dengan kondisi makro ekonomi dan kondisi industri suatu perusahaan. hingga berbagai indikator keuangan dan manajemen perusahaan. Dengan demikian, analisis fundamental merupakan analisis yang berbasis pada berbagai data riil untuk mengevaluasi atau memproyeksi nilai suatu saham. Faktor teknikal merupakan salah satu metode yang digunakan untuk penilaian saham, di mana dengan metode ini para analis melakukan evaluasi saham berbasis pada data-data statistik yang dihasilkan dari aktivitas perdagangan saham, seperti harga saham dan volume transaksi.
Fenomena harga saham ini menjadi suatu penelitian yang tidak asing lagi dalam penelitian. Hal ini mengenai faktor-faktor penentu yang mempengaruhi harga saham, seperti variabel penelitian, sektor, tahun, serta kondisi geografis penelitian yang berbeda dapat menghasilkan hasil yang tidak sama. Harga saham dipengaruhi oleh banyak faktor baik internal dan eksternal. Perbedaan ini menjadi motivasi penelitian karena merupakan masalah yang dapat diteliti lebih lanjut.

Penelitian ini bertujuan untuk mengetahui pengaruh earning per share, price to book value, return on asset, dan return on equity secara simultan maupun parsial terhadap harga saham pada perusahaan sektor keuangan yang terdaftar di Bursa Efek Indonesia tahun 2010 sampai 2014. Penelitian ini merupakan penelitian baru berbeda dari penelitian terdahulu dari tahun penelitian, sektor penelitian, periode masa penelitian, dan variabel penelitian. Pada penelitian terdahulu terkait EPS, PBV, ROA, dan ROE memiliki hasil yang berbeda dan bervariasi.

Rasio Earning Per Share (EPS) merupakan rasio yang digunakan untuk menunjukkan jumlah uang yang dihasilkan dari setiap lembar saham biasa (Hanum, 2009). Jika jumlah uang yang dihasilkan perusahaan meningkat maka nilai perusahaan yang ditunjukkan dengan harga saham akan meningkat pula. Earning Per Share menunjukkan besarnya laba bersih yang siap dibagikan kepada para pemegang saham. Semakin tinggi nilai EPS dapat diartikan bahwa semakin besar pula laba yang disediakan untuk pemegang saham. Penelitian yang dilakukan oleh Placido (2012) 
ada variabel EPS menunjukkan bahwa ada hubungan signifikan positif antara EPS dengan harga saham perusahaan. Hasil ini didukung oleh hasil penelitian Al- Dini et al. (2011) dan Uddin et al. (2013). Hasil penelitian ini berbeda dengan penelitian yang dilakukan oleh Darnita (2014) menunjukkan bahwa secara parsial variabel EPS tidak berpengaruh secara signifikan terhadap harga saham. Hasil penelitian ini didukung oleh hasil penelitian Simanjuntak dan Sari (2015).

Rasio Price to Book Value (PBV) merupakan rasio yang digunakan untuk mengukur kinerja harga pasar saham terhadap nilai bukunya (Najmiyah et.al., 2014). PBV juga menunjukkan seberapa jauh perusahaan mampu menciptakan nilai perusahaan relatif terhadap jumlah modal yang diinvestasikan. Jika nilai buku suatu perusahaan meningkat maka nilai perusahaan yang ditunjukkan dengan harga saham akan meningkat pula. Penelitian yang dilakukan oleh Fitriani (2016) pada variabel Price to Book Value (PBV) menunjukkan bahwa ada hubungan signifikan positif antara PBV dengan harga saham perusahaan. Hasil ini didukung oleh hasil penelitian Dita dan Mutaqi (2014). Hasil penelitian ini berbeda dengan penelitian yang dilakukan oleh Abimantrana (2013) menunjukkan bahwa variabel PBV tidak berpengaruh secara signifikan terhadap harga saham. Hasil penelitian ini didukung oleh hasil penelitian Beliani dan Budiantara (2015)

Rasio Return On Asset (ROA) ini sering digunakan pihak manajemen untuk mengukur kinerja keuangan perusahaan dan menilai kinerja operasional dalam memanfaatkan sumber daya yang dimiliki perusahaan (Hanum, 2009). Jika perusahaan mendapatkan keuntungan dari penggunaan seluruh aset (sumber daya) maka nilai perusahaan yang ditunjukkan dengan harga saham akan meningkat pula. Penelitian yang dilakukan oleh Murniati (2016) pada variabel Return On Asset (ROA) menunjukkan bahwa ada hubungan signifikan positif antara ROA dengan harga saham perusahaan. Hasil ini didukung oleh hasil penelitian Thim et al. (2012) dan Haque et al. (2012). Hasil penelitian ini berbeda dengan penelitian yang dilakukan oleh Satryo et al. (2016) menunjukkan bahwa secara parsial variabel ROA tidak berpengaruh secara signifikan terhadap harga saham. Hasil penelitian ini didukung oleh hasil penelitian Sugiarto (2014).

Kabajeh et al. (2012) menyatakan Return on Equity (ROE) adalah rasio profitabilitas yang digunakan untuk mengukur tingkat kembali perusahaan atau efektivitas perusahaan dalam menghasilkan laba yang merupakan hak dari pemilik modal. ROE dihitung sebagai laba bersih setelah pajak dibagi dengan total ekuitas pemegang saham. Rasio ini mengukur tingkat pemegang saham pengembalian investasi mereka dalam perusahaan. Jika perusahaan mendapatkan keuntungan dari penggunaan efektivitas modal maka nilai perusahaan yang ditunjukkan dengan harga saham akan meningkat pula. Penelitian yang dilakukan oleh Dadrasmoghadam dan Akbari (2015) pada variabel ROE menunjukkan bahwa ada hubungan signifikan positif antara ROE dengan harga saham perusahaan. Hasil ini didukung oleh hasil penelitian Wang et al. 2013 dan Sharif et al. (2015). Hasil penelitian ini berbeda dengan penelitian yang dilakukan 


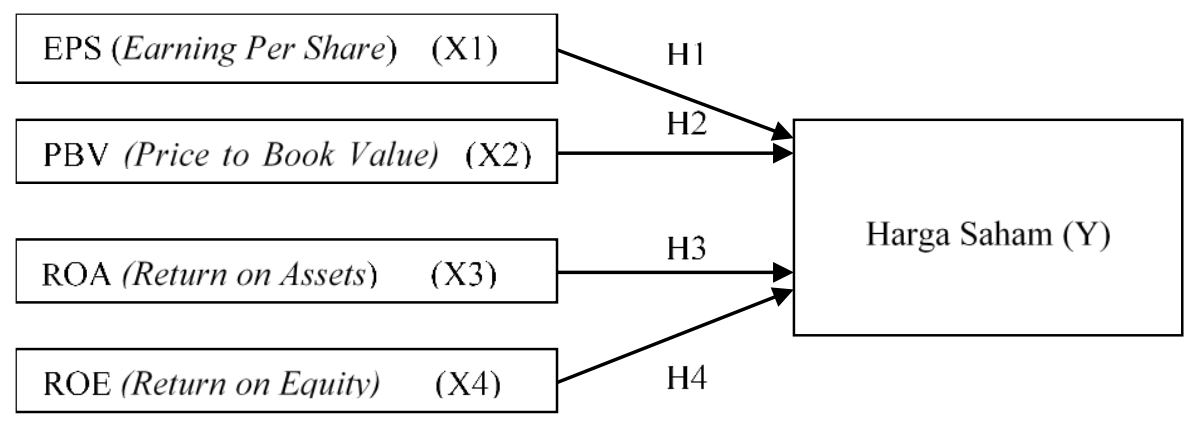

Gambar 1. Kerangka Pemikiran (dimodifikasi dari Hanum, 2009, Simanjuntak \& Sari, 2015)

oleh Sari dan Suhermin (2016) menunjukkan bahwa secara parsial variabel ROE tidak berpengaruh secara signifikan terhadap harga saham. Hasil penelitian ini didukung oleh hasil penelitian Talamati dan Pangemanan (2015). Berdasarkan kajian tersebut, hipotesis pada penelitian ini adalah:

H1 : bahwa diduga EPS berpengaruh signifikan positif terhadap harga saham.

H2 : bahwa diduga PBV berpengaruh signifikan positif terhadap harga saham.

H3 : bahwa diduga ROA berpengaruh signifikan positif terhadap harga saham.

H4 : bahwa diduga ROE berpengaruh signifikan positif terhadap harga saham.

\section{METODE}

Penelitian ini menggunakan data sekunder dari ICMD, maupun sumber lain. Populasi yang digunakan dalam penelitian ini adalah 51 perusahaan pada Sektor Keuangan yang terdaftar di Bursa Efek Indonesia (BEI) pada tahun pengamatan Periode 2010-2014. Teknik pengambilan sampel yang digunakan yaitu dengan metode purposive sampling, karena metode ini didasarkan pada tujuan spesifik dengan kriteria-kriteria yang telah ditentukan untuk memperoleh sampel yang mampu mewakili populasi, adapun telah diperoleh 47 perusahaan sebagai sampel penelitian dengan jumlah observasi sebanyak 237 perusahaan. Teknik analisis data menggunakan regresi linier berganda dan asumsi klasik.

Definisi operasional dalam penelitian ini, sebagai berikut:

Harga Saham

Harga saham dapat berubah naik ataupun turun dalam hubungan waktu yang begitu cepat. Hal tersebut dimungkinkan karena tergantung permintaan dan penawaran antara pembeli saham dengan penjual saham (Darmadji dan Fakhrudin, 2012).

\section{Earning Per Share}

Earning Per Share merupakan perbandingan antara laba bersih dengan jumlah saham yang beredar. Rahardjo (2009), EPS dihitung dengan formulasi sebagai berikut:

Earning Per Share $=\frac{\text { Laba bersih }}{\text { Jumlah saham yang beredar }}$

Price to Book Value

Price to Book Value merupakan perbandingan antara harga per lembar saham dengan nilai buku per lembar saham. Rahardjo (2009), PBV dihitung dengan formulasi sebagai berikut:

Price to Book Value $=\frac{\text { Harga per lembar saham }}{\text { Nilai buku per lembar saham }}$

Return on Asset

Return on Asset merupakan perbandingan antara laba setelah pajak dengan total aktiva. 
Tabel 1. Uji Multikolinearitas

\begin{tabular}{|c|c|c|c|}
\hline \multirow{2}{*}{ Model } & \multicolumn{2}{|c|}{ Collinearity Statistics } & \multirow{2}{*}{ Keterangan } \\
\hline & Tolerance & VIF & \\
\hline EPS & 0,632 & 1,581 & Terbebas dari multikolinearitas \\
\hline PBV & 0,931 & 1,074 & Terbebas dari multikolinearitas \\
\hline ROA & 0,715 & 1,398 & Terbebas dari multikolinearitas \\
\hline ROE & 0,494 & 2,023 & Terbebas dari multikolinearitas \\
\hline
\end{tabular}

Rahardjo (2009), ROA dihitung dengan formulasi sebagai berikut:

Return On Asset $=\frac{\text { Laba setelah pajak }}{\text { Total aktiva }}$

Return on Equity

Return on Equity merupakan perbandingan antara laba bersih dengan jumlah modal sendiri. Rahardjo (2009), ROE dihitung dengan formulasi sebagai berikut:

Return On Equity $=\frac{\text { Laba bersih }}{\text { Jumlah modal sendiri }}$

Metode analisis data yang digunakan dalam penelitian adalah menggunakan model persamaan regresi linier berganda sebagai berikut:

$$
H G S M_{i}=\alpha+\beta_{1} \cdot X_{1}+\beta_{2} \cdot X_{2}+\beta_{3} . X_{3}+\beta_{4} . X_{4}+e
$$

Keterangan:

HGSM = Harga Saham,

$\beta 1-\beta 4=$ Koefisien Regresi

$\alpha=$ Konstanta,

$\mathrm{X}_{1}=\mathrm{EPS}$,

$\mathrm{X}_{2}=\mathrm{PBV}$,

$X_{3}=R O A$,

$X_{4}=R O E$,

$\mathrm{e}=$ kesalahan pengguna (error term).

\section{HASIL DAN PEMBAHASAN}

Pengujian terhadap persyaratan analisis dilakukan terlebih dahulu. Pengujian tersebut meliputi uji normalitas, multikolinearitas, heterosedastisitas dan autokorelasi. Hasil uji normalitas terhadap residual yang dihasilkan model dengan menggunakan Kolmogorov-Smirnov Z diperoleh nilai 1,060 dengan signifikansi lebih besar dari 0,05. Hal ini menunjukkan bahwa data dalam model penelitian berdistribusi normal. Hasil uji multikolinearitas dengan menggunakan VIF juga menunjukkan tidak terjadi multikolinearitas karena semua nilai VIF di bawah 4 (lihat Tabel 1). Sementara itu hasil uji autokorelasi menunjukkan nilai asymptotic significant uji Runs test sebesar $0,059(>0,05)$ ini berarti bahwa tidak terjadi autokorelasi. Begitu juga hasil uji heterosedasatisitas dengan grafik scatterplots menunjukkan bahwa titik-titik menyebar secara acak dan tersebar ke berbagai arah (lihat Gambar 2). Hal ini dapat ditarik kesimpulan bahwa tidak terjadi heteroskedastisitas.

Hasil uji $\mathrm{F}$ berdasarkan output ANOVA pada Tabel 2 menunjukkan bahwa pengaruh variabel EPS, PBV, ROA, dan ROE secara bersama-sama berpengaruh terhadap variabel harga saham. Nilai $F$ test sebesar 21.999 dan nilai Sig. sebesar 0,000 yang menunjukkan bahwa pengaruh signifikan dan adanya pengaruh positif (dengan standar $0,05)$. Maka dapat ditarik kesimpulan bahwa variabel independen EPS, PBV, ROA, dan ROE secara simultan berpengaruh terhadap harga saham.

Dari hasil pengujian di atas, dapat diketahui bahwa adjusted $R$ square sebesar 0,262 atau $26,2 \%$ menunjukkan bahwa 


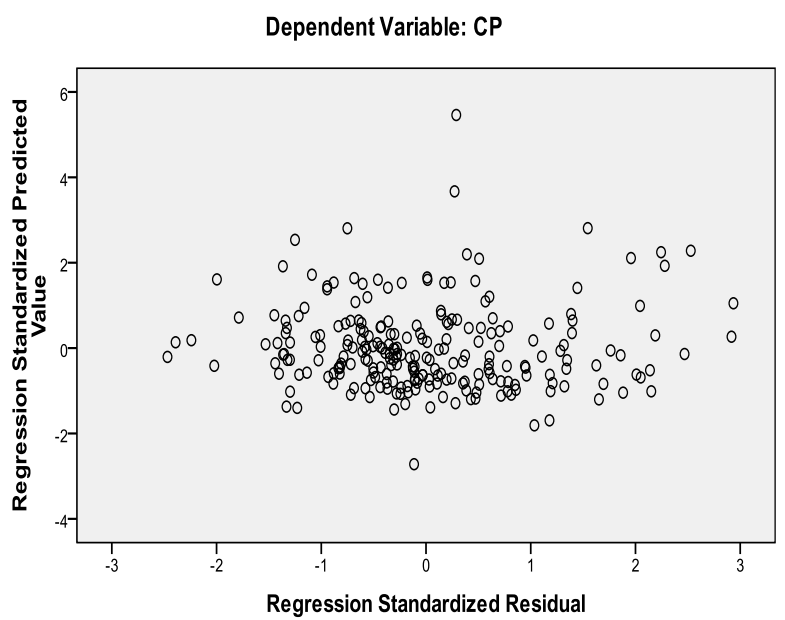

Gambar 2. Scatterplots Heteroskedastisitas

sebesar 26,2\% harga saham dapat dipengaruhi oleh variabel EPS, PBV, ROA, dan ROE. Pengaruh dari variabel lain yang tidak termasuk dalam persamaan regresi pada penelitian ini sebesar $73,8 \%$.

Hasil uji $\mathrm{t}$ ditunjukkan dengan nilai signifikansi EPS sebesar 0,001, nilai signifikansi PBV sebesar 0,000, nilai signifikansi ROA sebesar 0,000 dan nilai signifikan ROE sebesar 0,000. Keseluruhan variabel independen tersebut yaitu EPS, PBV, ROA, dan ROE memiliki nilai signifikansi di bawah 0,05. Hasil pengujian dari persamaan regresi tersebut dapat disimpulkan bahwa variabel EPS, PBV, ROA, dan ROE secara parsial berpengaruh signifikan terhadap harga saham.
Hipotesis Pertama $\left(\mathrm{H}_{1}\right)$ menyatakan bahwa diduga EPS berpengaruh signifikan positif terhadap harga saham, sehingga hipotesis 1 diterima. Hasil dari analisis ini EPS berpengaruh signifikan serta mempunyai arah positif terhadap harga saham. Jadi hipotesis ini terbukti dan konsisten dengan penelitian Al-Dini et al. (2011); Placido (2012) ; dan Uddin et al. (2013). Namun, hasil penelitian ini tidak sesuai dengan penelitian yang dilakukan oleh Darnita, (2014) yang menunjukkan bahwa secara parsial variabel EPS tidak berpengaruh secara signifikan terhadap harga saham. Hasil penelitian ini didukung oleh hasil penelitian Simanjuntak dan Sari (2015).

Tabel 2. Uji Regresi Linier Berganda

\begin{tabular}{cccc}
\hline Variabel & Koefisien & T & Sig. \\
\hline Konstant & $-0,251$ & $-4,942$ & 0,000 \\
EPS & 0,000 & $-3,343$ & 0,001 \\
PBV & 0,075 & 4,908 & 0,000 \\
ROA & 0,020 & 3,598 & 0,000 \\
ROE & 0,017 & 4,376 & 0,000 \\
\hline R Square & 0,274 & & \\
Adj R Square & 0,262 & & \\
F & 21,999 & & \\
Sig. F & 0,000 & &
\end{tabular}


Hipotesis Kedua $\left(\mathrm{H}_{2}\right)$ menyatakan bahwa diduga PBV berpengaruh positif terhadap harga saham, sehingga hipotesis 2 diterima. Hasil dari analisis ini PBV berpengaruh signifikan dan memiliki arah positif terhadap harga saham. Jadi hipotesis ini terbukti dan konsisten dengan penelitian Dita dan Mutaqi (2014) dan Fitriani (2016) yang menjelaskan bahwa PBV memiliki hubungan yang kuat dengan harga saham. Namun, hasil penelitian ini berbeda dengan penelitian yang dilakukan oleh Abimantrana (2013) menunjukkan bahwa variabel PBV tidak berpengaruh secara signifikan terhadap harga saham. Hasil penelitian ini didukung oleh hasil penelitian Beliani dan Budiantara (2015).

Hipotesis Ketiga $\left(\mathrm{H}_{3}\right)$ menyatakan bahwa diduga ROA berpengaruh signifikan positif terhadap harga saham. Hasil dari analisis ini ROA berpengaruh signifikan dan mempunyai arah positif terhadap harga saham, sehingga hipotesis 3 diterima. Hipotesis ini terbukti dan konsisten dengan penelitian Thim et al. (2012); Haque et al. (2012); dan Murniati (2016) menjelaskan bahwa ROA mempunyai pengaruh signifikan serta searah dengan harga saham. Namun, hasil penelitian ini berbeda dengan penelitian yang dilakukan oleh Sugiarto (2014) dan Satryo et al. (2016) menunjukkan bahwa secara parsial variabel ROA tidak berpengaruh secara signifikan terhadap harga saham.

Hipotesis keempat $\left(\mathrm{H}_{4}\right)$ menyatakan bahwa diduga ROE berpengaruh signifikan positif terhadap harga saham, sehingga hipotesis 4 diterima. Hasil dari analisis ini ROE berpengaruh signifikan, dan mempunyai arah positif terhadap harga saham. Jadi hipotesis ini terbukti dan konsisten dengan
Wang et al. (2013); Dadrasmoghadam dan Akbari (2015); dan Sharif et al. (2015 bahwa variabel ROE berpengaruh positif terhadap harga saham, tetapi hasil penelitian ini berbeda dengan penelitian yang dilakukan oleh Talamati dan Pangemanan (2015) dan Sari dan Suhermin (2016) menunjukkan bahwa secara parsial variabel ROE tidak berpengaruh secara signifikan terhadap harga saham.

\section{SIMPULAN}

Variabel EPS, PBV, ROA dan ROE memiliki pengaruh signifikan terhadap harga saham secara simultan dan parsial. Variabel EPS, PBV, ROA dan ROE memiliki pengaruh sebesar $26,2 \%$ terhadap harga saham pada Sektor Keuangan periode tahun 2010-2014. Pengaruh dari variabel lain yang tidak termasuk dalam persamaan regresi pada penelitian ini sebesar $73,8 \%$.

Dari hasil analisis tersebut di atas dan kesimpulan yang diperoleh bagi peneliti berikutnya hendaknya lebih diperbanyak jumlah sampel, periode serta pengamatan untuk lebih diperpanjang, serta memperhitungkan kondisi ekonomi makro, internal non finansial, situasi politik dan kondisi umum regional serta internasional.

\section{DAFTAR PUSTAKA}

Abimantrana, Alep Pradipta. (2013). The Influence Financial Performance On Stock Price Around Publication Date of Financial Statements. Jurnal IImiah Mahasiswa FEB Universitas Brawijaya. (2)2.

Al -Dini, Seyed Heidar Mirfakhr. Hassan Dehghan Dehavi. Elham Zarezadeh. (2011). Fitting the Relationship between 
Financial Variables and Stock Price through Fuzzy Regression Case study: Iran Khodro Company. International Journal of Business and Social Science. (2)11.

Apriliyanti, Devia Amirta. (2015). Analisis Pengaruh Kinerja Keuangan Terhadap Harga Saham Perusahaan Perbankan di Bursa Efek Indonesia, Naskah Publikasi Fakultas Ekonomi dan Bisnis Universitas Muhammadiyah Surakarta.

Arkan, Thomas. (2016). The Importance of Financial Ratios in Predicting Stock Price Trends: A Case Study in Emerging Markets, Finanse, Rynki Finansowe. Ubezpieczenia. 79(1).

Beliani, Maria Makdalena Inge. M. Budiantara. (2015). Pengaruh Price Earning Ratio dan Price to Book Value Terhadap Harga Saham Perusahaan Asuransi yang Terdaftar di Bursa Efek Indonesia Tahun 2009-2012. Jurnal Riset Akuntansi Mercu Buana. 1(1).

Budi, Rahardjo. (2009). Dasar-dasar Analisis Fundamental Saham Laporan Keuangan Perusahaan. Jakarta: Gajah Mada University Press.

Dadrasmoghadam, Amir. Seyed Mohammad Reza Akbari. (2015). Relationship between Financial Ratios in the Stock Prices of Agriculture-Related Companies Accepted On the Stock Exchange for Iran. Research Journal of Fisheries And Hydrobiology. 10(9).

Darmadji, Tjiptono, dan Fakhruddin. (2012). Pasar Modal di Indonesia (Edisi 3). Jakarta: Salemba Empat.

Darnita, Elis. (2014). Analisis Pengaruh Return On Assets (ROA), Return On Equity (ROE), Net Profit Margin (NPM) Dan Earning Per Share (EPS) Terhadap Harga Saham (Studi Pada Perusahaan Food Dan Beverages Yang Terdaftar Di Bursa Efek Indonesia (BEI) Pada Tahun 2008-2012). (tidak dipublikasikan).
Fakultas Ekonomi dan Bisnis Jurusan Manajemen Universitas Dian Nuswantoro Semarang.

Dita, Amalia Husna. Isrochmani Murtaqi. (2014). The Effect of Net Profit Margin, Price to Book Value and Debt to Equity Ratio to Stock Return in Indonesian Consumer Good Industry. Journal of Business and Management. 3(3).

Fitriani, Ramadhani Srifitra. (2016). Pengaruh NPM,PBV, dan DER Terhadap Harga Saham pada Perusahaan Sub Sektor Makanan dan Minuman di Bursa Efek Indonesia. e-Journal Administrasi Bisnis. 4(3).

Hanum, Zulia. (2009). Pengaruh Return On Asset (ROA), Return On Equity (ROE), Dan Earning Per Share (EPS) Terhadap Harga Saham Pada Perusahaan Otomotif yang Terdaftar di Bursa Efek Indonesia Periode 2008-2011. Jurnal Manajemen \& Bisnis. $8(2)$.

Haque, Md. Reiazul. Rony Kumar Datta. Rajib Dey Md. Mostafizur Rahman. (2013). Financial Variables Having Significant Impact on Market Price of Shares. Research Journal of Finance and Accounting. 4(15).

Institute for Economic and Financial Research. Indonesian Capital Market Directory 2013 (23 ${ }^{\text {th }}$ Edition). Vol II. Indonesia: ECFIN.

Institute for Economic and Financial Research. Indonesian Capital Market Directory 2015 (23 $3^{\text {th }}$ Edition). Vol II. Indonesia: ECFIN.

Jensen, M. C and Meckling, W.H. (1976). Theory of the Firm: Managerial Behavior, Agency Costs and Ownership Structure. Journal of Financial Economics. 3(4).

Jogiyanto, H.M. (2010). Teori Portofolio dan Analisis Investasi (Edisi 7). Yogyakarta: BPFE. 
Kabajeh, Majed Abdel Majid. Al- Nu'aimat Said Mukhled Ahmed. Dahmash Firas Naim. (2012). The Relationship between the ROA, ROE, dan ROI Ratios with Jordanian Insurance Public Companies Market Share Prices. International Journal of Humanities and Social Science. 2(11).

Murniati, Sitti. (2016). Effect of Capital Structure, Company Size and Profitability on the Stock Price of Food and Beverage Companies Listed on the Indonesia Stock Exchange. Information Management and Business Review. 8(1).

Najmiyah. Edy Sujana. Ni Kadek Sinarwati. (2014). Pengaruh Price to Book Value (PBV), Price Earning Ratio (PER), dan Debt to Equity Ratio (DER) Terhadap Return Saham pada Industri Real Estate dan Property yang Terdaftar di Bursa Efek Indonesia Periode 2009-2013. e-Journal S1 Ak Universitas Ganesha. 2(1).

Pasaribu, Rowland Bismark Fernando. (2008). The Influence of Corporate Fundamental to Stock Price in Indonesian Public Companies. Jurnal Ekonomi dan Bisnis. 2(2).

Placido M. Menaje, Jr. (2012). Impact of Selected Financial Variables on Share Price of Publicly Listed Firms in the Philippines. American International Journal of Contemporary Research. 2(9).

Sari, Yuni Indra. Suhermin. (2016). Pengaruh Faktor-Faktor Fundamental Terhadap Harga Saham pada Perusahaan Telekomunikasi. Jurnal IImu dan Riset Manajemen. 5(7).

Satryo, Abhimada Gatuth. Nur Aini Rokhmania. Pepie Diptyana. (2016). The Influence of profitability ratio, market ratio, and solvency ratio on the share prices of companies listed LQ45 Index. The Indonesian Accounting Review. 6(1).
Sharif, Taimur.Harsh Purohi. Rekha Pillai. (2015). Analysis of Factors Affecting Share Prices: The Case of Bahrain Stock Exchange. International Journal of Economics and Finance. 7(3).

Simanjuntak, Pibrianti Dahlia Lastria. Sari Raina Linda. (2015). Analisis Pengaruh Return On Asset, Net Profit Margin, Earning Per Share Terhadap Return Saham Pada Perusahaan Perbankan Yang Terdaftar Di BEl. Jurnal Ekonomi dan Keuangan. 2(7).

Sugiarto, Rengga Jeni Ery. (2014). Pengaruh DER, ROA Terhadap Harga Saham pada Perusahaan Telekomunikasi di BEI. Jurnal IImu \& Riset Manajemen. 3(9).

Sulistyanto, Sri. (2008). Manajemen Laba Teori dan Model Empiris. Jakarta: Grasindo.

Talamati, Mohamad Rianto. Pangemanan, Sifrid S. (2015). The Effect Of Earnings Per Share (EPS) \& Return On Equity (ROE) On Stock Price Of Banking Company Listed In Indonesia Stock Exchange (IDX) 20102014. Jurnal EMBA. 3(2).

Thim, Chan Kok. Yap Voon Choong. Nur Qasrina Binti Asri. (2012). Stock Performance of the Property Sector in Malaysia, Journal of Modern Accounting and Auditing. 8(2).

Uddin, Md. Reaz. S.M. Zahidur Rahman. Md. Rajib Hossain. (2013). Determinants of Stock Prices in Financial Sector Companies in Bangladesh- A Study on Dhaka Stock Exchange (DSE). Interdisciplinary Journal of Contemporary Research in Business. 5(3).

Wang, Junjie. Fu, Gang. Luo, Chao. (2013). Accounting Information and Stock Price Reaction of Listed Companies Empirical Evidence from 60 Listed Companies in Shanghai Stock Exchange. Journal of Business \& Management. 2(2) 